\title{
Environmental Impact on Surface and Ground Water Pollution from Mining Activities in Ikpeshi, Edo State, Nigeria
}

\author{
G. N. Idris' ${ }^{1}$, G. O. Asuen², 0. J. Ogundele ${ }^{1}$ \\ ${ }^{1}$ Department of Minerals and Petroleum Resources Engineering, Auchi Polytechnic, Auchi, Nigeria \\ ${ }^{2}$ Department of Geology, University of Benin, Benin City, Nigeria \\ Email: Updeen177@yahoo.com, macsalem14@yahoo.com
}

Received 17 February 2014; revised 14 March 2014; accepted 12 April 2014

Copyright (C) 2014 by authors and Scientific Research Publishing Inc.

This work is licensed under the Creative Commons Attribution International License (CC BY).

http://creativecommons.org/licenses/by/4.0/

(c) (i) Open Access

\begin{abstract}
The study was carried out to evaluate the surface and groundwater condition from mining activities in Ikpeshi and its environs in Akoko Edo Local Government Area of Edo State, Nigeria. Twenty water samples were randomly collected and analyzed-one borehole water sample, two hands dug wells, eight river samples and nine quarry pits water samples. The physiochemical, heavy metal and bacteriological analysis of the water sample, as well as the variables were compared with those of the World Health Organization (WHO) standard (2008), United State Environmental Protection Agencies (USEPA) standard (2012) and National Agency For Food, Drug Administration And Control (NAFDAC) in Nigeria to determine their suitability for drinking and domestic purposes. The variables determined are: $\mathrm{pH}$ ranges from $7.67-8.56 \mathrm{mg} / \mathrm{l}$ which is suggestive of neutral to alkaline in character, calcium ranges from $5.12-2416 \mathrm{mg} / \mathrm{l}$, turbidity ranges from 1.16 - 15.32 $\mathrm{mg} / \mathrm{l}$, total dissolved solid (Tds) ranges from $90-366 \mathrm{mg} / \mathrm{l}$ and total hardness ranges from 58.65 $187.37 \mathrm{mg} / \mathrm{l}$, fall within WHO standard, are suggestive of concentration of detergent from soap, calcium, magnesium, suspended solid particles and colloidal matters from some of the water samples. While iron ranges from $0.08-0.16 \mathrm{mg} / \mathrm{l}$, potassium ranges from $0.02-0.18 \mathrm{mg} / \mathrm{l}$, chloride ranges from $30.03-120.13 \mathrm{mg} / \mathrm{l}$, sulphate ranges from $1.03-5.36 \mathrm{mg} / \mathrm{l}$, nitrate ranges from 0.01 $0.23 \mathrm{mg} / \mathrm{l}$, lead ranges from $0-0.01 \mathrm{mg} / \mathrm{l}$, Zinc ranges from $0-0.08 \mathrm{mg} / \mathrm{l}$, copper ranges from 0 $0.02 \mathrm{mg} / \mathrm{l}$ and magnesium ranges from $1.38-6.56 \mathrm{mg} / \mathrm{l}$, fall within standards. Coliform count ranges from $0-14 \mathrm{mg} / \mathrm{l}$. The water should be treated before the consumption because of its high concentration of detergent, suspended particles, faecal materials and calcium from the water samples. The quarry pits should be reclaimed and rehabilitate after mining. Alkaline materials should be used to neutralize the rock pile area, dumped site, tailing and mine pit itself to avoid acid generation.
\end{abstract}

\section{Keywords}

Environment, Impact, Water, Pollution, Mining, Activities

How to cite this paper: Idris, G.N., Asuen, G.O. and Ogundele, O.J. (2014) Environmental Impact on Surface and Ground Water Pollution from Mining Activities in Ikpeshi, Edo State, Nigeria. International Journal of Geosciences, 5, 749-755. 


\section{Introduction}

In any environment, there is a strong relationship between human activities and water pollution of that environment due to anthropogenic activities resulting from the growth of industries and technological advancement.

The sources of pollution in mining terrain in Ikpeshi are open pits, waste disposal area, haulage roads, processing plant mills, tailing, and waste rock piles area.

Direct degradation can occur to ground water situation downhill from a surface mine by the flow of contaminated drainage from the mine. This mine drainage can come from pits, ponds or from rain fall infiltration and groundwater flow during mining and often reclamation. Groundwater pollution would result from the same toxic overburden.

Indirect degradation of groundwater could result from blasting which causes a temporary shaking of the rock and results in the new rock fracture near working area of the mine. Blasting can also cause the old pre-existing rock fracture to become more open or permeable, by loosening mineral debris or cement in this fracture; this could affect nearly vertical fractures located up to several hundred feet away from the surface mine causing vertical leakage of pond mine drainage from nearby abandoned deep mines to underlying aquifers.

Water is considered polluted when it is altered in composition or condition direct or indirectly as a result of activities of man so that it becomes unsuitable or less suitable for any or all of the functions or purposes for which it would be suitable in its natural state [1]. Pollution of water whatever description is actionable [2]. Environmental pollution and contamination are becoming a common occurrence in part of developing ward [3]. Chemistry of ground water, its classification, standard and usage studies were carried out [4], undertook a case study of Nigeria. In tropical countries like ours, the high temperature partially accounts for the water dissolving more materials. Elements like lead, copper, cadmium, chromium etc. are regarded as toxic elements. Therefore, their presence in water above permissible limits stipulate by WHO and NAFDAC which are peculiar to Nigeria can affect the central nervous system [5].

Ikpeshi mining companies are the largest in Edo State, Nigeria and have a processing capacity of 175,000 tons per day of crushed ore. The catchment area contains mineralized rocks which contain solid minerals, and usually have elevated metal level. As the trace metal content of river water is normally controlled by the abundance of metal in the rock of the catchment area and by their mobility.

The land surface of the study area is dominated by sand stone ridges to south, and there are generally undulating schist outcrop around Ikpeshi town. Marble is located in the north-eastern part of the area and this is where the quarry operation is mainly located. Most of the stream is fed by spring water and see pages through some joints and fracture zones in the underlying basement rocks.

\section{Methodology}

Reconnaissance survey was carried out to locate strategic position where samples can be collected so as to obtain reliable result.

Polythene bottles containers were used for the collection of water samples at each location, samples were taken at the rivers, bore hole, hand dug wells and open quarry sites. Before collection of samples, the polythene bottles containers were rinsed again by the water from which samples were to be taken. This was done for each location where samples were collected. Samples were collected at different locations randomly.

The samples were duplicated and corked tightly and well labelled according to their location and number. The samples were kept in refrigerator at a temperature of about $4^{\circ} \mathrm{C}$ to prevent further bacterial replication before they were taken to the laboratory for further analysis on the next day.

The refrigerator of the water is a means of preventing the spontaneous increase of bacterial species in the water and to maintain the natural state of the water samples.

\subsection{Determination of $\mathrm{pH}$ in Water (Apha 460)}

To measure the $\mathrm{pH}$ of the samples collected, $\mathrm{pH}$ meter (Model Testr-1), Beaker (100 ml capacity) and Buffer solutions of pH 4.01 and 10.01 were used. At a given temperature, the intensity of the acidic or basic character of a solution is indicated by hydrogen ion activity. In the field and laboratory, $\mathrm{pH}$ is electrometrically measured using a $\mathrm{pH}$ meter with a glass electrode. $\mathrm{pH}$ meter was calibrated and the following procedures were followed to measure water samples $\mathrm{pH}$ level: 
- The pH meter electrode was used copiously rinsed with distilled water.

- Pour about $100 \mathrm{ml}$ of water samples into a clean $100 \mathrm{ml}$ capacity beaker.

- The electrode end of the $\mathrm{pH}$ meter was inserted into the sample and $\mathrm{pH}$ reading was taken after wards.

- Both the $\mathrm{pH}$ meter electrode and the samples were copiously rinsed with distilled water.

- $100 \mathrm{ml}$ of water samples was poured into a clean $100 \mathrm{ml}$ capacity beaker.

- The electrode end of the $\mathrm{pH}$ meter was inserted into the sample, $\mathrm{pH}$ readings taken.

- All the $\mathrm{pH}$ values were recorded and tabulated.

\subsection{Determination of Electrical Conductivity in Water}

Electrical conductivity of water is a numerical expression of the ability of an aqueous solution to carry an electric current. To determine electrical conductivity in water, electrical conductivity meter (pioneer 65) and $0.01 \mathrm{M}$ $\mathrm{KCl}$ solution were used. The equipment was calibrated. The following procedures were followed to measure the samples:

- Rinse the EC meter electrode copiously with distilled water, followed by the sample.

- Pour about $100 \mathrm{ml}$ of water samples into a clean $100 \mathrm{ml}$ capacity beaker.

- Insert the electrode end of the meter into the sample, press READ button and wait for a stable reading.

- Record the EC value.

Lovibond comparator and turbidity meter model 800 were used to determined colour measurement and turbidity respectively. Also, total hardness was determined using buffer solution, 2-drops of eriochrome black T indicator was added and titrated with $0.01 \mathrm{~N}$ EDTA from wine colour to blue end-point.

\subsection{Determination of Salinity as Chloride Water}

Mohr method was employed which involved silver nitrate as titrant and potassium chromate as the end point indicator. The chloride ion present in the wastewater sample is precipitated as white silver chloride.

Colorimetric method was employed in the determination of sulphate ion. Volumetric flasks (100 ml capacity), pipettes (10 ml capacity), cuvette (25 ml capacity) and HACH DR2000 (absorbance mode) were used with the following reagents: barium chloride salt, $\mathrm{NaCl}-\mathrm{HCl}$ solution and alcohol-glycerol mixture.

\subsection{Determination of Phosphate in Water}

HACH DR2000 (Absorbance Mode), 50 ml Volumetric flasks, 10 ml pipette, 25 ml cuvette, Hot plate and 250 $\mathrm{ml}$ round bottom flask were used with the following reagents/chemical: ammonium molybdate-antimonyl solution, Ascorbic acid (2\% w/v) solution, Phosphate standard stock solution (1000 mg/L), perchloric acid, NaOH solution, $6 \mathrm{M}$ and methyl orange indicator.

Oxidation method, multiple tube test (APHA 9222A) and brucine method were used to analysis heavy metals in water wet, total coliform bacteria and nitrate in water.

\section{Results and Discussion}

The obtained data from water analysed are showed in Tables 1-3.

The result shows that turbidity, hardness, TDS, magnesium and calcium are very high in some samples. That calcium had the greatest values both for fresh water and drinking water respectively. That the environment is more of calcite than dolomite make it calcitic dolomite environment. Copper, Zinc, pH, conductivity, hardness, chloride, and sulphate occur in reasonable concentrations which are within the average values as compared to WHO, NAFDAC and USEPA values. From the potential health effects like urinary tract infection, bacteraemia and diarrhoea from the injection of water containing such concentration above mentioned parameters, the water collected should be treated before consumption.

The colour of the samples collected, ranges from 0 - 1 hazen units were not all cleared as a result of high concentration of dissolved calcium and magnesium including sample SP4 which is the borehole. The $\mathrm{pH}$ of surface and groundwater in the study area generally ranges from 7.61 - 8.65, which means that the $\mathrm{pH}$ is generally neutral to alkaline. Electrical conductivity generally ranges from $182.1-733(\mu \mathrm{S} / \mathrm{m})$, which means the sample are good conductor of electricity (Table 4).

The result of the water analysis in the study area show that $\mathrm{pH}$ of the groundwater and surface water ranges 
Table 1. Laboratory data for samples analysed.

\begin{tabular}{|c|c|c|c|c|c|c|c|c|c|c|c|c|c|c|c|c|}
\hline Sample & $\mathrm{Ph}$ & Temp & TDS & Cond & Colour & Turbidity & $\begin{array}{c}\text { Total } \\
\text { hardness }\end{array}$ & $\mathrm{Ca}$ & Mg & $\mathrm{Na}$ & K & Chloride & TOC & Sulphate & Phosphate & Nitrate \\
\hline & & $\left({ }^{\circ} \mathrm{C}\right)$ & $(\mathrm{mg} / \mathrm{l})$ & $(\mu \mathrm{s} / \mathrm{cm})$ & (Lu) & (N.T.U) & $(\mathrm{mg} / \mathrm{l})$ & $(\mathrm{mg} / \mathrm{l})$ & $(\mathrm{mg} / \mathrm{l})$ & $(\mathrm{mg} / \mathrm{l})$ & $(\mathrm{mg} / \mathrm{l})$ & $(\mathrm{mg} / \mathrm{l})$ & $(\mathrm{mg} / \mathrm{l})$ & $(\mathrm{mg} / \mathrm{l})$ & $(\mathrm{mg} / \mathrm{l})$ & $(\mathrm{mg} / \mathrm{l})$ \\
\hline 1-SWS & 7.91 & 29.4 & 247 & 496 & 1 & 15.32 & 109.72 & 17.61 & 5.92 & 7.21 & 0.18 & 85.05 & 0.01 & 2.43 & 0.51 & 0.09 \\
\hline 2-RWS & 8.32 & 29.1 & 183 & 366.2 & 1 & 2.31 & 117.89 & 16.64 & 4.98 & 5.42 & 0.15 & 80.02 & 0.03 & 1.72 & 0.18 & 0.03 \\
\hline 3-QWS & 8.02 & 28.6 & 249 & 498 & 0 & 1.43 & 178.32 & 20.03 & 7.62 & 7.71 & 0.16 & 90.08 & 0.02 & 1.57 & 0.14 & 0.07 \\
\hline 4-HDW & 7.67 & 28.9 & 366 & 733 & 1 & 13.52 & 187.37 & 24.16 & 6.56 & 8.35 & 0.11 & 120.13 & 0.07 & 5.36 & 1.63 & 0.23 \\
\hline 5-BHW & 7.81 & 29.6 & 90 & 182.1 & 0 & 1.72 & 58.65 & 5.12 & 1.58 & 2.18 & 0.09 & 30.03 & 0.01 & 2.15 & 0.93 & 0.01 \\
\hline 6-QWS & 7.78 & 30.4 & 129 & 258.5 & 1 & 8.64 & 104.25 & 10.88 & 3.34 & 4.21 & 0.10 & 65.11 & 0.02 & 1.03 & 0.07 & 0.03 \\
\hline 7-QWS & 8.22 & 29.6 & 178 & 354.2 & 0 & 1.57 & 115.97 & 14.45 & 4.63 & 4.28 & 0.13 & 75.26 & 0.01 & 1.17 & 0.11 & 0.02 \\
\hline 8-QWS & 8.56 & 28.1 & 113 & 224.9 & 0 & 1.38 & 77.56 & 7.23 & 1.93 & 2.81 & 0.05 & 57.94 & 0.01 & 1.36 & 0.13 & 0.01 \\
\hline 9-QWS & 8.45 & 28.4 & 114 & 228.3 & 0 & 1.16 & 84.53 & 7.52 & 2.23 & 1.72 & 0.03 & 61.25 & 0.03 & 1.04 & 0.07 & 0.01 \\
\hline 10-RWS & 8.12 & 28.2 & 227 & 453 & 1 & 4.16 & 127.36 & 22.83 & 1.38 & 2.39 & 0.02 & 78.14 & 0.02 & 1.24 & 0.03 & 0.02 \\
\hline 11-SWS & 8.41 & 28.3 & 251 & 421 & 1 & 1.63 & 171.89 & 15.21 & 4.23 & 6.35 & 0.17 & 80.13 & 0.02 & 1.33 & 0.16 & 0.04 \\
\hline 12-SWS & 8.56 & 28.4 & 117 & 231.6 & 0 & 1.41 & 53.87 & 13.42 & 1.45 & 5.14 & 0.04 & 52.12 & 0.01 & 1.18 & 0.08 & 0.03 \\
\hline 13-QWS & 8.01 & 29.3 & 216 & 412 & 1 & 1.91 & 108.93 & 8.32 & 1.83 & 4.36 & 0.16 & 71.13 & 0.03 & 1.06 & 0.12 & 0.01 \\
\hline 14-HDW & 7.72 & 28.6 & 296 & 728 & 1 & 12.24 & 172.42 & 18.54 & 1.32 & 2.16 & 0.03 & 29.58 & 0.02 & 2.09 & 0.92 & 0.06 \\
\hline 15-SWS & 8.21 & 29.4 & 182 & 359.2 & 0 & 2.21 & 112.45 & 21.05 & 2.12 & 1.83 & 0.08 & 58.86 & 0.01 & 1.13 & 0.14 & 0.02 \\
\hline 16-QWS & 8.62 & 28.2 & 172 & 298.4 & 1 & 1.52 & 138.32 & 6.13 & 3.15 & 4.27 & 0.14 & 81.56 & 0.01 & 1.09 & 0.02 & 0.05 \\
\hline 17-QWS & 7.95 & 29.2 & 106 & 214.8 & 0 & 14.82 & 56.47 & 7.01 & 4.06 & 7.43 & 0.02 & 92.45 & 0.03 & 1.27 & 0.52 & 0.01 \\
\hline 18-QWS & 8.47 & 28.6 & 224 & 443 & 1 & 2.41 & 123.24 & 19.26 & 1.98 & 6.08 & 0.15 & 65.34 & 0.02 & 1.31 & 0.15 & 0.03 \\
\hline 19-SWS & 8.08 & 28.9 & 234 & 478 & 1 & 13.42 & 162.21 & 20.06 & 4.06 & 7.12 & 0.13 & 48.67 & 0.02 & 1.05 & 0.17 & 0.04 \\
\hline 20-RWS & 8.01 & 29.3 & 257 & 499 & 1 & 8.73 & 105.47 & 5.93 & 1.81 & 2.13 & 0.05 & 76.07 & 0.01 & 1.23 & 0.23 & 0.07 \\
\hline
\end{tabular}

Table 2. Laboratory result.

\begin{tabular}{|c|c|c|c|c|c|c|c|c|c|}
\hline \multirow{2}{*}{ Sample code } & Bicarbonate & $\mathbf{F e}$ & $\mathbf{P b}$ & Mn & Zn & $\mathbf{C u}$ & Coliform count & Cd & $\mathrm{Cr}$ \\
\hline & (mg/l) & $(\mathrm{mg} / \mathrm{l})$ & (mg/l) & (mg/l) & (mg/l) & (mg/l) & $\mathrm{Cfu} / \mathrm{ml}$ & $(\mathrm{mg} / \mathrm{l})$ & $(\mathrm{mg} / \mathrm{l})$ \\
\hline 1-SWS & 50.12 & 0.08 & BDL & 0.05 & 0.02 & BDL & 14 & BDL & BDL \\
\hline 2-RWS & 40.73 & 0.12 & 0.01 & BDL & 0.06 & BDL & 11 & BDL & $\mathrm{BDL}$ \\
\hline 3-QWS & 57.45 & 0.10 & BDL & 0.02 & 0.05 & 0.01 & 2 & BDL & BDL \\
\hline 4-HDW & 84.93 & 0.13 & 0.01 & 0.03 & BDL & BDL & 9 & BDL & BDL \\
\hline 5-BHW & 24.65 & 0.09 & BDL & BDL & 0.03 & 0.01 & 4 & BDL & BDL \\
\hline 6-QWS & 31.83 & 0.12 & BDL & 0.02 & 0.07 & BDL & 2 & BDL & BDL \\
\hline 7-QWS & 35.63 & 0.16 & 0.01 & BDL & 0.05 & BDL & 0 & BDL & BDL \\
\hline 8-QWS & 21.83 & 0.09 & BDL & 0.03 & 0.03 & 0.01 & 0 & BDL & BDL \\
\hline 9-QWS & 22.25 & 0.12 & BDL & 0.03 & 0.08 & BDL & 4 & BDL & BDL \\
\hline 10-RWS & 54.5 & 0.08 & BDL & 0.01 & 0.05 & 0.02 & 6 & BDL & BDL \\
\hline 11-SWS & 38.23 & 0.08 & 0.01 & 0.02 & 0.03 & BDL & 13 & BDL & 0.01 \\
\hline 12-RWS & 22.09 & 0.09 & 0.01 & 0.04 & 0.02 & BDL & 2 & BDL & BDL \\
\hline 13-QWS & 32.72 & 0.11 & BDL & 0.01 & 0.04 & 0.01 & 12 & BDL & BDL \\
\hline 14-HDW & 55.43 & 0.09 & BDL & BDL & 0.03 & BDL & 4 & BDL & BDL \\
\hline 15-SWS & 41.86 & 0.13 & BDL & 0.03 & 0.06 & 0.01 & 0 & $\mathrm{BDL}$ & BDL \\
\hline 16-QWS & 28.19 & 0.08 & 0.01 & BDL & 0.08 & 0.02 & 0 & BDL & BDL \\
\hline 17-QWS & 50.09 & 0.12 & 0.01 & 0.01 & 0.03 & BDL & 2 & BDL & BDL \\
\hline 18-QWS & 34.28 & 0.15 & BDL & 0.05 & 0.02 & 0.01 & 14 & BDL & BDL \\
\hline 19-SWS & 48.62 & 0.14 & 0.01 & 0.01 & 0.04 & 0.02 & 6 & BDL & BDL \\
\hline 20-RWS & 51.53 & 0.09 & BDL & 0.03 & 0.05 & BDL & 0 & BDL & BDL \\
\hline
\end{tabular}

Note: BDL (below detection limit i.e. < 0.001). 
Table 3. Comparison of the obtained values with the World Health Organization standard [6].

\begin{tabular}{|c|c|c|c|c|}
\hline Parameter & $\begin{array}{c}\text { Highest } \\
\text { desirable }(\mathrm{mg} / \mathrm{l})\end{array}$ & $\begin{array}{c}\text { Maximum } \\
\text { permissible level (mg/l) }\end{array}$ & $\begin{array}{l}\text { Range of values obtained } \\
\text { from analysis (mg/l) }\end{array}$ & Remarks \\
\hline $\mathbf{P h}$ & 7.08 .9 & $6.5-9.5$ & $7.61-8.65$ & It is neutral to alkaline \\
\hline Conductivity & $900(\mu \mathrm{S} / \mathrm{m})$ & $1200(\mu \mathrm{S} / \mathrm{m})$ & $182.1-733$ & \\
\hline Total hardness & 100 & 100 & $77.56-187.37$ & Moderately to very hard water \\
\hline Magnesium & 20 & 20 & $1.38-6.56$ & Extremely low \\
\hline Calcium & 0.01 & 0.07 & $5.12-25.16$ & Highly concentrated \\
\hline Sulphate & 250 & 500 & $1.03-2.43$ & Suitable for drinking \\
\hline Iron & 1.0 & 3.0 & $0.08-0.16$ & Ok \\
\hline Nitrate & 10 & 50 & $0.01-0.23$ & Ok \\
\hline Lead & 0.01 & 0.01 & BDL - 0.01 & OK \\
\hline Cadmium & 0.003 & 0.003 & BDL & $\mathrm{OK}$ \\
\hline Chromium & 0.05 & 0.05 & BDL & $\mathrm{OK}$ \\
\hline Turbidity & 5.0 & 5.0 & $1.16-15.32$ & 7 samples out of 20 are not suitable \\
\hline Sodium & - & 200 & $1.72-8.35$ & Suitable \\
\hline Manganese & 0.0 & 0.4 & BDL-0.05 & Suitable \\
\hline Zinc & 0.01 & 3.0 & BDL-0.08 & Suitable \\
\hline Copper & 0.5 & 2.0 & BDL-0.02 & Suitable \\
\hline Total coliforms & Not allowed & Not allowed & $0-14$ & Only 5 samples are ok \\
\hline $\begin{array}{c}\text { Total } \\
\text { organic carbon }\end{array}$ & - & 5 & $0.01-0.07$ & Ok \\
\hline $\begin{array}{l}\text { Total dissolved } \\
\text { solids }\left(\mathrm{mg} / \mathrm{ll}^{*}\right.\end{array}$ & & 500 & $90-366$. & Ok \\
\hline Potassium $^{* *}$ & 10.0 & 11.0 & $0.02-0.18$ & Ok \\
\hline
\end{tabular}

"United State Environmental Protection Agency, 2012. [7]. ${ }^{* *}$ National Agency for Food, Drug Administration and Control [8]. BDL: below detection limit.

Table 4. Water classification according to its hardness [9].

\begin{tabular}{cc}
\hline Hardness & Types of hardness \\
\hline $\mathbf{0}-\mathbf{6 0}$ & Soft water \\
$\mathbf{6 1}-\mathbf{1 2 0}$ & Moderately hard water \\
$\mathbf{1 2 1}-\mathbf{1 8 0}$ & Hard water \\
$>\mathbf{1 8 0}$ & Very hard water \\
\hline
\end{tabular}

from 77.56 - 187.37, meaning that the water hardness falls within moderately hard water, hard water and very hard water. The Iron in the sample ranges from $0.08-0.16$. The use of fertilizer for agriculture shows little trace of potassium concentration in the study area which ranges from $0.02-0.18$. The magnesium concentration of the analyzed water sample ranges from 1.38 - 6.56. The concentration of calcium ranges from 5.12 - $25.16 \mathrm{mg} / \mathrm{l}$.

The presence of coliform count bacterial in a water body indicates that the water has contaminated with the faecal material of man or other animals. The presence of faecal contamination is an indicator that a potentials health risk exist for individuals exposed to this water. The values of coliform count, ranges from 0 - 14 . No faecal materials are allowed in drinking water but are prominent in some of the samples especially in stream water samples. It presence makes the samples examined contaminated and inadequate for drinking.

The total dissolved solid ranges from $90-366 \mathrm{mg} \cdot \mathrm{l}^{-1}$ and it falls within the WHO permissible limit of 500 $\mathrm{mg} \cdot \mathrm{l}^{-1}$. 


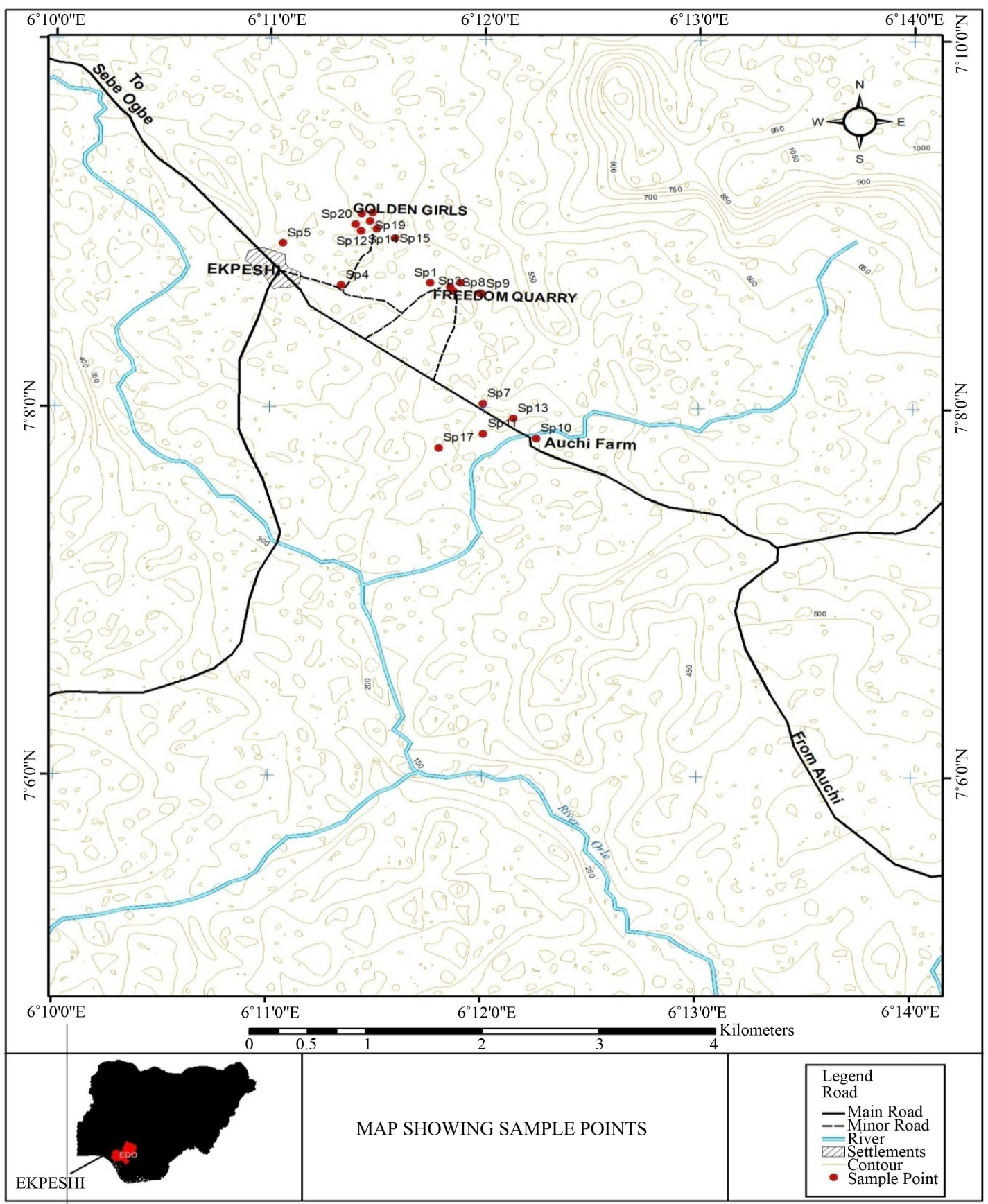

\section{Conclusions}

The findings of this study serve as the basis for making the following conclusions:

1) The measured pollutants found their way to the ground and surface water system through path ways such as fracture zones and pore space into the aquifer zone, through run-off, infiltration and percolations thereby contaminating the portable water.

2) Turbidity, hardness, total dissolved solids, magnesium and calcium are very high in concentration in some of the samples. Total hardness was also very high and calcium had the greatest concentration both for fresh water and drinking water respectively.

3) Copper, Zinc, pH, conductivity, hardness, chloride, and sulphate occur in reasonable concentrations which are within the average values as compared to WHO, NAFDAC and USEPA standards. 
4) Faecal materials are higher in the obtained samples that were closer to the settlement than far away from the settlement.

\section{Recommendations}

Based on the findings of this study, the following recommendations have been proffered:

1) From the potential health effects from the injection of water containing such concentration above mentioned parameters, the water collected should be treated before consumption.

2) Total pollution or degradation prevention cannot be attained but the important thing is to reduce the effect of pollution and degradation to the nearest minimum.

3) Mine pits should be reclaimed for future use.

4) The Environmental Protection Agency of Edo State (EDSEPA) should live up to its statutory obligation of maintaining standards.

\section{References}

[1] Panamello, R. and Mohano, O. (1973) Principle and Problems of Groundwater Resource with Cases Example from Developing Countries. Riparian Right and Pollution.

[2] Ezenabor, B.O. (1991) Pollution of Water Whatever Description Is Actionable Riparian Right.

[3] Egboka, B.C.E., Nwankwo, G.I., Orajaka, I.P. and Jiofor, A.O. (1989) Guidelines for Drinking Water Quality (World Water) Illinois Groundwater Pollution.

[4] Offodile, M.E. (1992) An Approach to Groundwater Study and Development in Nigeria. Mecon Geology and Engineering Services Ltd., Jos.

[5] Oteze, G.E. (1981) Water Resources in Nigeria Environment. Vol. 3, Springer, Bertlin Heidelberg, 177-184.

[6] World Health Organisation (1994) International Standard for Drinking Water. 8th Edition, Geneva, 53 p.

[7] United State Environmental Protection Agency (2012) Edition of the Drinking Water Standards and Health Advisories.

[8] National Agency for food and Drugs Administration and Control, Nigeria (2008) To Safeguard the Public Health of the Nation.

[9] Hem, J.D. (1970) Groundwater Hydrology. McGraw-Hill, Kogakusha, LTD, Tokyo, 480 p. 